\title{
Analisis Pupuk Kandang Ayam dan Biourine Terhadap Pertumbuhan dan Hasil Dari Benih dan Punggul Tanaman Kangkung Darat (Ipomea Reptans)
}

\author{
Ketut Agung Sudewa, Luh Komang Sulasmini Mudra \\ Program Studi Agroteknologi, Fakultas Pertanian, Universitas Warmadewa \\ E-mail: agsudewa63@gmail.com
}

\begin{abstract}
This study aims to determine the effect of chicken manure and biourine on the growth of stem of ground water kangkung, so it is known that the best type of fertilizer used for growth and yield of kangkung plants after the first harvest. This experiment used a randomized block design (RBD) with a factorial experimental pattern consisting of two factors. The first factor is the dosage of biourine (B) consisting of 4 levels ie B0: control, B1: 200 L ha ${ }^{-1}, B 2$ : $400 \mathrm{~L} \mathrm{ha}^{-1}$, and B3: $600 \mathrm{~L} \mathrm{ha}^{-1}$. The second factor is dose of cow manure (K) consist of 2 levels ie K0: control and K1: 20 ton $\mathrm{ha}^{-1}$. The results concluded that there was no interaction between the treatment of chicken manure with biourin liquid fertilizer to all growth variables and the results observed in ground kangkung plants derived from stump except the variables of the harvest index. Treatment of chicken manure 20 tons ha gave the highest economical fresh weight per plant that is $70.48 \mathrm{~g}$ and increased by $84.02 \%$ compared to the economical fresh weight per plant obtained in the treatment without chicken manure is $38.30 \mathrm{~g}$, while the treatment dose of $400 \mathrm{~L} \mathrm{ha}$ ${ }^{1}$ biourine fertilizer gave the highest economical fresh weight per plant that is $55.66 \mathrm{~g}$ and increased by $7.63 \%$ compared to the economical fresh weight per plant obtained in the treatment without biourine fertilizer ie $51.71 \mathrm{~g}$.
\end{abstract}

Keywords: Manure, biourine, seeds, punggul, Ipomea reptans

\section{Pendahuluan}

Kangkung merupakan salah satu anggota famili Convolvulaceae. Tanaman kangkung dapat digolongkan sebagai tanaman sayur. Kangkung terdiri dari beberapa jenis, diantaranya kangkung air (Ipomoea aquatica Forsk), kangkung darat (Ipomoea reptans Poir), dan kangkung hutan (Ipomoea crassiculatus Rob.) (Suratman et al., 2000).

Kangkung darat merupakan tanaman yang relatif tahan kekeringan dan memiliki daya adaptasi luas terhadap berbagai keadaan lingkungan tumbuhan, mudah pemeliharaannya, dan memiliki masa panen yang pendek (Suratman et al., 2000). Budidaya kangkung darat secara intensif dan beorientasi ke arah agribisnis akan memberikan keuntungan yang cukup besar (Rukmana, 1994).

Kangkung merupakan tanaman yang tumbuh lebih dari satu tahun. Tanaman kangkung memiliki sistem perakaran tunggang dan cabang-cabangnya menyebar kesemua arah dapat menembus tanah sampai kedalaman 60-100 cm dan melebar secara mendatar pada radius $100-150 \mathrm{~cm}$ atau lebih terutama pada jenis kangkung air (Rismunandar, 1994).

Batang tanaman kangkung berbentuk bulat panjang sukuler, beruas-ruas dan didalamnya berongga. Ruas-ruas batang dibatasi dengan buku, dan pada tiap buku dapat tumbuh akar, tunas daun dan bunga (Nazaruddin, 2000). Tangkai daun melekat pada buku-buku batang dan pada ketiak daunnya terdapat mata tunas yang dapat tumbuh menjadi percabangan baru. Bentuk daun umumnya seperti jantung hati, ujung daun runcing ataupun tumpul, permukaan daun sebelah atas berwarna hijau muda (Aksi Agraris Kanisius, 2002).

Pemanenan kangkung darat dapat dilakukan menggunakan 2 cara yaitu dengan cara pemotongan dan pencabutan. Pemotongan di lakukan dengan cara memotong bagian bawah batang kangkung yang 
hanya di sisakan dengan ketinggian batang $2 \mathrm{~cm}$. Sedangkan pencabutan di lakukan dengan mencabut seluruh bagian tanaman kangkung hingga hingga ke akar. Dilakukannya pemotongan bertujuan untuk memperoleh panen kedua, karena bagian bawah kangkung tersebut dapat tumbuh kembali jika dilakukan pemupukan.

Pupuk kandang memiliki sifat yang alami dan tidak merusak tanah, menyediakan unsur hara makro dan mikro. Pupuk kandang juga berfungsi untuk meningkatkan daya menahan air, aktivitas mikrobiologi tanah, nilai kapasitas tukar kation dan memperbaiki struktur tanah (Syekhfani, 2000). Beberapa hasil penelitian aplikasi pupuk kandang ayam selalu memberikan respon tanaman yang terbaik pada musim pertama, karena pupuk kandang ayam relatif lebih cepat terdekomposisi serta mempunyai kadar hara yang cukup bila dibandingkan dengan jumlah unit yang sama dengan pupuk kandang lain (Widowati et al., 2005).

Pemberian pupuk cair biourine merupakan salah satu alternatif untuk meningkatkan ketersediaan, kecukupan, dan efisiensi serapan hara bagi tanaman yang mengandung mikroorganisme sehingga dapat mengurangi penggunaan pupuk anorganik (NPK) dan meningkatkan hasil tanaman secara maksimal. Hasil penelitian Sutari (2010) menunjukkan bahwa biourine sapi pada konsentrasi $200 \mathrm{ml} \mathrm{L-1} \mathrm{air}$ memberikan hasil tanaman sawi hijau yang paling baik.

Tujuan dari penelitian ini adalah untuk mengetahui pengaruh pemberian pupuk kandang ayam dan biourine terhadap pertumbuhan hasil punggul tanaman kangkung darat, sehingga diketahui jenis pupuk yang paling baik digunakan bagi pertumbuhan dan hasil tanaman kangkung darat setelah panen pertama. Hipotesis penelitian ini yaitu Diduga pupuk kandang ayam memberikan pertumbuhan hasil punggul kangkung darat lebih baik di bandingkan dengan pupuk cair biourine.

\section{Bahan dan Metode}

Rancangan percobaan yang digunakan adalah dengan rancangan acak kelompok dan analisis sidik ragam serta dilanjutkan dengan uji BNT taraf 5\%. Perlakuan yang digunakan dalam penelitian ini yaitu dosis pupuk kandang ayam dan dosis pupuk cair biourin dan penanaman dimulai dari punggul. Percobaan ini dilaksanakan di kebun percobaan Fakultas Pertanian Universitas Warmadewa Denpasar dengan ketinggian tempat \pm 0-75 $\mathrm{m}$ di atas permukaan laut. Penelitian ini dilaksanakan dari tanggal 2 Mei sampai dengan 2 Juni 2016.

Percobaan ini merupakan percobaan faktorial dengan rancangan acak kelompok (RAK). Perlakuan terdiri dari dua faktor, yaitu dosis biourine (B) dan dosis pupuk kadang sapi (K). Faktor pertama adalah dosis biourine (B) terdiri atas 4 taraf yaitu B0: kontrol, B1: $200 \mathrm{~L} \mathrm{ha}^{-1}=20 \mathrm{ml}$ per petak, B2: $400 \mathrm{~L} \mathrm{ha}^{-1}$ $=40 \mathrm{ml}$ per petak, dan B3: $600 \mathrm{~L} \mathrm{ha}^{-1}=60 \mathrm{ml}$ per petak. Faktor kedua adalah dosis pupuk kandang sapi (K) terdiri dari 2 taraf yaitu K0: kontrol dan K1: 20 ton ha ${ }^{-1}$. Dengan demikian terdapat 8 perlakuan kombinasi, masing-masing perlakuan diulang 3 kali sehingga didapat 24 petak percobaan.

Variabel yang diamati meliputi tinggi tanaman, jumlah cabang per tanaman, jumlah daun per tanaman, indek luas daun umur 20 hari setelah panen pertama, berat segar hasil ekonomis, berat segar hasil berangkasan, berat kering oven hasil ekonomis, berat kering oven berangkasan, dan indeks panen.

\section{Hasil dan Pembahasan}

Hasil signifikansi pengaruh dosis pupuk kandang ayam dan dosis pupuk biourine terhadap 
pertumbuhan dan hasil dari benih dan punggul tanaman kangkung darat dapat dilihat pada Tabel 1. Hasil analisis sidik ragam diperoleh perlakuan pupuk kandang ayam $(\mathrm{K})$ tidak berpengaruh nyata terhadap sebagian variabel yang diamati kecuali variabel tinggi tanaman, jumlah cabang daun, berat segar ekonomis, berat segar berangkasan dan berat kering matahari ekonomis yang menunjukan pengaruh nyata $(\mathrm{p}<0,5)$ sampai sangat nyata $(\mathrm{p}<0,1)$. Sedangkan dosis pupuk cair biourine (B) tidak berpengaruh nyata terhadap semua variabel yang diamati serta interaksi antara dosis pupuk kandang ayam dan dosis pupuk biourine $(\mathrm{KxB})$ menunjukan pengaruh tidak nyata terhadap sebagian besar variabel yang diamati kecuali pada variabel indeks panen yang menunjukan pengaruh nyata $(\mathrm{p}<0,05)$.

Tabel 1

Signifikansi Pengaruh Dosis Pupuk Kandang Ayam dan Dosis Pupuk Biourine terhadap Pertumbuhan dan Hasil dari Benih dan Punggul Tanaman Kangkung Darat

\begin{tabular}{cllcc}
\hline \multirow{2}{*}{ No } & \multicolumn{1}{c}{ Variabel } & \multicolumn{3}{c}{ Perlakuan } \\
\cline { 3 - 5 } & & $\mathrm{K}$ & $\mathrm{B}$ & $\mathrm{K} \times \mathrm{B}$ \\
\hline 1 & Tinggi tanaman $(\mathrm{cm})$ & $* *$ & $\mathrm{~ns}$ & $\mathrm{~ns}$ \\
2 & Jumlah cabang per tanaman & $\mathrm{ns}$ & $\mathrm{ns}$ & $\mathrm{ns}$ \\
3 & Jumlah daun per tanaman (helai) & $\mathrm{ns}$ & $\mathrm{ns}$ & $\mathrm{ns}$ \\
4 & Indeks luas daun umur 14 & $\mathrm{ns}$ & $\mathrm{ns}$ & $\mathrm{ns}$ \\
5 & Indeks luas daun umur 19 & $* *$ & $\mathrm{~ns}$ & $\mathrm{~ns}$ \\
6 & Berat segar ekonomis per tanaman $(\mathrm{g})$ & $*$ & $\mathrm{~ns}$ & $\mathrm{~ns}$ \\
7 & Berat segar berangkasan per tanaman $(\mathrm{g})$ & $\mathrm{ns}$ & $\mathrm{ns}$ & $\mathrm{ns}$ \\
8 & Berat kering oven ekonomis $(\mathrm{g})$ & $\mathrm{ns}$ & $\mathrm{ns}$ & $\mathrm{ns}$ \\
9 & Berat kering oven berangkasan $(\mathrm{g})$ & $\mathrm{ns}$ & $\mathrm{ns}$ & $\mathrm{ns}$ \\
10 & Indeks panen $(\%)$ & $\mathrm{ns}$ ) pengaruh tidak nyata $(\mathrm{p}>0,05)$
\end{tabular}

\section{Tinggi Tanaman}

Hasil penelitian menunjukkan bahwa rata-rata tinggi tanaman tertinggi diperoleh pada perlakuan pupuk kandang ayam 20 ton.ha ${ }^{-1}(\mathrm{~K} 1)$ yaitu $38,40 \mathrm{~cm}$ yang berbeda dengan perlakuan tanpa pupuk kandang ayam (K0) 32,61 cm. Pada perlakuan pupuk cair biourine rata-rata tinggi tanaman tertinggi diperoleh pada dosis pupuk cair biourine 200 L.ha $^{-1}$ (B1) yaitu $37.29 \mathrm{~cm}$ dibandingkan dengan dosis pupuk cair biourine $600 \mathrm{~L} . h a^{-1}$ (B3) yaitu $34.42 \mathrm{~cm}$ dan dosis pupuk cair biourine $400 \mathrm{~L}^{\mathrm{ha}} \mathrm{ha}^{-1}$ (B2) yaitu $35.94 \mathrm{~cm}$ serta perlakuan tanpa pupuk cair biourine (B0) yaitu $34.45 \mathrm{~cm}$ (Tabel 2).

Tabel 2

Rata-rata Tinggi Tanaman Kangkung darat karena Pengaruh Dosis Pupuk Kandang Ayam dan Pupuk Biourine

\begin{tabular}{ll}
\hline Perlakuan & Tinggi Tanaman $(\mathrm{cm})$ \\
\hline Pupuk Kandang Ayam $(\mathrm{K})$ & \\
0 ton ha-1 $(\mathrm{K} 0)$ & $32,61 \mathrm{~b}$ \\
20 ton ha-1 $^{-1}(\mathrm{~K} 1)$ & $38,44 \mathrm{a}$ \\
\hline BNT $5 \%$ & 2,25 \\
\hline Pupuk Cair Biourine (B) & $34,45 \mathrm{a}$ \\
$0 \mathrm{~L} \mathrm{ha}(\mathrm{B} 0)$ & $37,29 \mathrm{a}$ \\
$200 \mathrm{~L} \mathrm{ha}^{-1}(\mathrm{~B} 1)$ & $35,94 \mathrm{a}$ \\
$400 \mathrm{~L} \mathrm{ha}^{-1}(\mathrm{~B} 2)$ & $34,42 \mathrm{a}$ \\
$600 \mathrm{~L} \mathrm{ha}$ & - \\
\hline BNT $0.05 \%$ & - \\
\hline Keterangan : Angka-angka yang diikuti oleh huruf yang sama pada faktor yang sama berarti berbeda tidak nyata \\
pada uji BNT 5\%.
\end{tabular}




\section{Jumlah Cabang Daun}

Rata-rata jumlah cabang daun tertinggi diperoleh pada perlakuan pupuk kandang ayam 20 ton.ha ${ }^{-1}$ (K1) yaitu 5,90 cabang yang berbeda dengan perlakuan tanpa pupuk kandang ayam (K0) 5,13 cabang. Pada perlakuan pupuk cair biourine rata-rata jumlah cabang daun tertinggi diperoleh pada perlakuan tanpa pupuk cair biourine (B0) dan pada dosis pupuk cair biourine 400 L.ha ${ }^{-1}$ (B2) yaitu masing-masing 5,77 cabang, dibandingkan dengan dosis pupuk cair biourine 200 L.ha $^{-1}$ (B1) yaitu 5,34 cabang serta dosis pupuk cair biourine 600 L.ha $^{-1}$ (B3) yaitu 5,19 batang (Tabel 3).

Tabel 3

Rata-rata Jumlah Cabang Daun Karena Pengaruh Dosis Pupuk Kandang Ayam dan Pupuk Biourine

\begin{tabular}{ll}
\hline Perlakuan & $\begin{array}{l}\text { Jumlah Cabang Daun } \\
\text { (cabang) }\end{array}$ \\
\hline Pupuk Kandang Ayam (K) & $5,13 \mathrm{~b}$ \\
0 ton ha-1 $(\mathrm{K} 0)$ & $5,90 \mathrm{a}$ \\
20 ton ha $^{-1}(\mathrm{~K} 1)$ & 0,52 \\
\hline BNT $5 \%$ & \\
\hline Pupuk Cair Biourine (B) & 5,77 a \\
0 L ha-1 $(\mathrm{B} 0)$ & 5,34 a \\
$200 \mathrm{~L} \mathrm{ha}^{-1}(\mathrm{~B} 1)$ & 5,77 a \\
$400 \mathrm{~L} \mathrm{ha}^{-1}(\mathrm{~B} 2)$ & $5,19 \mathrm{a}$ \\
$600 \mathrm{~L} \mathrm{ha}{ }^{-1}(\mathrm{~B} 3)$ & - \\
\hline BNT 0.05\% & \\
\hline Keterangan : Angka-angka yang diikuti oleh huruf yang sama pada faktor yang sama berarti berbeda tidak nyata \\
pada uji BNT 5\%
\end{tabular}

\section{Jumlah Daun}

Rata-rata jumlah daun tertinggi diperoleh pada perlakuan pupuk kandang ayam 20 ton.ha ${ }^{-1}$ (K1) yaitu 28,36 helai yang berbeda dengan perlakuan tanpa pupuk kandang ayam (K0) 26,86 helai. Pada perlakuan pupuk cair biourine rata-rata jumlah daun tertinggi diperoleh pada dosis pupuk cair biourine 400 L.ha $^{-1}$ (B2) yaitu 28,09 helai dibandingkan dengan dosis pupuk cair biourine 200 L.ha $^{-1}$ (B1) yaitu 27,18 helai dan dosis pupuk cair biourine $600 \mathrm{~L}^{-h^{-1}}$ (B3) yaitu 27,33 helai serta perlakuan tanpa pupuk cair biourine (B0) yaitu 27,83 helai (Tabel 4).

Tabel 4

Rata-rata Jumlah Daun Karena Pengaruh Dosis Pupuk Kandang Ayam dan Pupuk Biourine

\begin{tabular}{|c|c|}
\hline Perlakuan & $\begin{array}{l}\text { Jumlah Daun } \\
\text { (cabang) }\end{array}$ \\
\hline \multicolumn{2}{|l|}{ Pupuk Kandang Ayam (K) } \\
\hline 0 ton $\mathrm{ha}^{-1}(\mathrm{~K} 0)$ & $26,86 \mathrm{a}$ \\
\hline 20 ton $\mathrm{ha}^{-1}(\mathrm{~K} 1)$ & $28,36 \mathrm{a}$ \\
\hline BNT 5\% & - \\
\hline \multicolumn{2}{|l|}{ Pupuk Cair Biourine (B) } \\
\hline $0 \mathrm{~L} \mathrm{ha}^{-1}(\mathrm{~B} 0)$ & $27,83 \mathrm{a}$ \\
\hline $200 \mathrm{~L} \mathrm{ha}^{-1}$ (B1) & 27,18 a \\
\hline $400 \mathrm{~L} \mathrm{ha}^{-1}(\mathrm{~B} 2)$ & $28,09 \mathrm{a}$ \\
\hline $600 \mathrm{~L} \mathrm{ha}^{-1}(\mathrm{~B} 3)$ & $27,33 \mathrm{a}$ \\
\hline BNT $0.05 \%$ & - \\
\hline
\end{tabular}




\section{Indeks Luas Daun}

Rata-rata indeks luas daun 20 hari setelah panen pertama tertinggi diperoleh pada perlakuan pupuk kandang ayam 20 ton ha $^{-1}$ (K1) yaitu 6,51 yang berbeda dengan perlakuan tanpa pupuk kandang ayam (K0) 5,51. Pada perlakuan pupuk cair biourine rata-rata indeks luas daun 20 hari setelah panen pertama tertinggi diperoleh pada dosis pupuk cair biourine $200 \mathrm{~L} \mathrm{ha}^{-1}$ (B1) yaitu 6,38 dibandingkan dengan perlakuan tanpa pupuk cair biourine (B0) yaitu 5,80 dan dosis pupuk cair biourine 400 L.ha $^{-1}$ (B2) yaitu 5,97 serta dosis pupuk cair biourine 600 L.ha $^{-1}$ (B3) yaitu 6,04 (Tabel 5)

Tabel 5

Rata-rata Indeks Luas Daun Karena Pengaruh Dosis Pupuk Kandang Ayam dan Pupuk Biourine

\begin{tabular}{|c|c|}
\hline Perlakuan & $\begin{array}{l}\text { Indeks Luas Daun } 19 \text { hari setelah panen pertama } \\
\text { (cabang) }\end{array}$ \\
\hline \multicolumn{2}{|c|}{ Pupuk Kandang Ayam (K) } \\
\hline 0 ton $\mathrm{ha}^{-1}(\mathrm{~K} 0)$ & $5,59 \mathrm{a}$ \\
\hline 20 ton $\mathrm{ha}^{-1}(\mathrm{~K} 1)$ & $6,51 \mathrm{a}$ \\
\hline BNT 5\% & - \\
\hline \multicolumn{2}{|c|}{ Pupuk Cair Biourine (B) } \\
\hline $0 \mathrm{~L} \mathrm{ha}^{-1}(\mathrm{~B} 0)$ & $5,80 \mathrm{a}$ \\
\hline $200 \mathrm{~L} \mathrm{ha}^{-1}(\mathrm{~B} 1)$ & $6,38 \mathrm{a}$ \\
\hline $400 \mathrm{~L} \mathrm{ha}^{-1}(\mathrm{~B} 2)$ & $5,97 \mathrm{a}$ \\
\hline $600 \mathrm{~L} \mathrm{ha}^{-1}(\mathrm{~B} 3)$ & $6,04 \mathrm{a}$ \\
\hline BNT $0.05 \%$ & - \\
\hline
\end{tabular}

\section{Berat Segar Ekonomis}

Rata-rata berat segar ekonomis tertinggi diperoleh pada perlakuan pupuk kandang ayam 20 ton.ha ${ }^{-1}$ (K1) yaitu 70,48 g yang berbeda dengan perlakuan tanpa pupuk kandang ayam (K0) 38,30 g. Pada perlakuan pupuk cair biourine rata-rata berat segar ekonomis tertinggi diperoleh pada dosis pupuk cair biourine 400 L.ha $^{-1}$ (B2) yaitu 55,66 g dibandingkan dengan perlakuan tanpa pupuk biourine (B0) yaitu $51,71 \mathrm{~g}$ dan dosis pupuk cair biourine $200 \mathrm{~L}^{\mathrm{h}} \mathrm{ha}^{-1}$ (B1) yaitu 54,80 g serta dosis pupuk cair biourine 600 L.ha ${ }^{-1}$ (B3) yaitu 55,41 g (Tabel 6).

Tabel 6

Rata-rata Berat Segar Ekonomis Karena Pengaruh Dosis Pupuk Kandang Ayam dan Pupuk Biourine

\begin{tabular}{|c|c|}
\hline Perlakuan & Berat Segar Ekonomis (g) \\
\hline \multicolumn{2}{|l|}{ Pupuk Kandang Ayam (K) } \\
\hline 0 ton $\mathrm{ha}^{-1}(\mathrm{~K} 0)$ & $38,30 \mathrm{~b}$ \\
\hline 20 ton $\mathrm{ha}^{-1}(\mathrm{~K} 1)$ & $70,48 \mathrm{a}$ \\
\hline BNT 5\% & 12,47 \\
\hline \multicolumn{2}{|l|}{ Pupuk Cair Biourine (B) } \\
\hline $0 \mathrm{~L} \mathrm{ha}^{-1}(\mathrm{~B} 0)$ & $51,71 \mathrm{a}$ \\
\hline $200 \mathrm{~L} \mathrm{ha}^{-1}(\mathrm{~B} 1)$ & $54,80 \mathrm{a}$ \\
\hline $400 \mathrm{~L} \mathrm{ha}^{-1}(\mathrm{~B} 2)$ & $55,66 \mathrm{a}$ \\
\hline $600 \mathrm{~L} \mathrm{ha}^{-1}(\mathrm{~B} 3)$ & $55,41 \mathrm{a}$ \\
\hline BNT $0.05 \%$ & - \\
\hline
\end{tabular}

\section{Berat Segar Berangkasan}

Rata-rata berat segar berangkasan tertinggi diperoleh pada perlakuan pupuk kandang ayam 20 ton.ha ${ }^{-1}$ (K1) yaitu 14,86 g yang berbeda dengan perlakuan tanpa pupuk kandang ayam (K0) 11,20 g. Pada perlakuan pupuk cair biourine rata-rata berat segar ekonomis tertinggi diperoleh pada perlakuan tanpa 
Analisis Pupuk Kandang Ayam dan Biourine Terhadap Pertumbuhan dan Hasil Dari Benih dan Punggul Tanaman Kangkung Darat (Ipomea Reptans)

pupuk cair biourine (B0) yaitu 13,60 g dibandingkan dengan dosis pupuk cair biourine 200 L.ha $^{-1}$ (B1) yaitu 12,62 g dan dosis pupuk cair biourine $400 \mathrm{~L}^{-h^{-1}}{ }^{-}$(B2) yaitu 12,81 g serta dosis pupuk cair biourine 600 L.ha ${ }^{-1}$ (B3) yaitu 13,09 g (Tabel 7).

Tabel 7

Rata-rata Berat Segar Berangkasan Karena Pengaruh Dosis Pupuk Kandang Ayam dan Pupuk Biourine

\begin{tabular}{ll}
\hline Perlakuan & Berat Segar Berangkasan (g) \\
\hline Pupuk Kandang Ayam (K) & $11,20 \mathrm{~b}$ \\
0 ton ha-1 $(\mathrm{K} 0)$ & $14,86 \mathrm{a}$ \\
20 ton ha $^{-1}(\mathrm{~K} 1)$ & 3,40 \\
\hline BNT 5\% & $13,60 \mathrm{a}$ \\
\hline Pupuk Cair Biourine (B) & 12,62 a \\
\hline L ha ${ }^{-1}(\mathrm{~B} 0)$ & 12,81 a \\
$200 \mathrm{~L} \mathrm{ha}^{-1}(\mathrm{~B} 1)$ & 13,09 a \\
$400 \mathrm{~L} \mathrm{ha}{ }^{-1}(\mathrm{~B} 2)$ & - \\
$600 \mathrm{~L} \mathrm{ha}{ }^{-1}(\mathrm{~B} 3)$ & \\
\hline BNT 0.05\% & \\
\hline Keterangan : Angka-angka yang diikuti oleh huruf yang sama pada faktor yang sama berarti berbeda tidak nyata \\
pada uji BNT 5\%
\end{tabular}

\section{Berat Kering Oven Ekonomis}

Rata-rata berat kering oven ekonomis tertinggi diperoleh pada perlakuan pupuk kandang ayam 20 ton.ha ${ }^{-1}(\mathrm{~K} 1)$ yaitu 3,93 g yang berbeda dengan perlakuan tanpa pupuk kandang ayam (K0) 2,36 g. Perlakuan pupuk cair biourine rata-rata berat kering oven ekonomis tertinggi diperoleh pada dosis pupuk cair biourine 600 L.ha $^{-1}$ (B3) yaitu 3,70 g dibandingkan dengan dosis pupuk cair biourine 400 L.ha $^{-1}$ (B2) yaitu 2,83 g dan perlakuan tanpa pupuk cair biourine (B0) yaitu 2,93 g serta dosis pupuk cair biourine 200 L.ha $^{-1}$ (B1) yaitu 3,13 g (Tabel 8)

Tabel 8

Rata-rata Berat Kering Oven Ekonomis Karena Pengaruh Dosis Pupuk Kandang Ayam dan Pupuk Biourine

\begin{tabular}{|c|c|}
\hline Perlakuan & Berat Kering Oven Ekonomis (g) \\
\hline \multicolumn{2}{|l|}{ Pupuk Kandang Ayam (K) } \\
\hline 0 ton ha ${ }^{-1}(\mathrm{~K} 0)$ & $2,36 \mathrm{a}$ \\
\hline 20 ton ha $^{-1}(\mathrm{~K} 1)$ & $3,93 \mathrm{a}$ \\
\hline BNT $5 \%$ & - \\
\hline \multicolumn{2}{|l|}{ Pupuk Cair Biourine (B) } \\
\hline $0 \mathrm{~L} \mathrm{ha}^{-1}(\mathrm{~B} 0)$ & $2,93 \mathrm{a}$ \\
\hline $200 \mathrm{~L} \mathrm{ha}^{-1}$ (B1) & $3,13 \mathrm{a}$ \\
\hline $400 \mathrm{~L} \mathrm{ha}^{-1}(\mathrm{~B} 2)$ & $2,83 \mathrm{a}$ \\
\hline $600 \mathrm{~L} \mathrm{ha}^{-1}(\mathrm{~B} 3)$ & $3,70 \mathrm{a}$ \\
\hline BNT $0.05 \%$ & - \\
\hline
\end{tabular}

\section{Berat Kering Oven Berangkasan}

Rata-rata berat kering oven berangkasan tertinggi diperoleh pada perlakuan pupuk kandang ayam 20 ton.ha ${ }^{-1}(\mathrm{~K} 1)$ yaitu $1,95 \mathrm{~g}$ yang berbeda dengan perlakuan tanpa pupuk kandang ayam (K0) 1,75 g. Pada perlakuan pupuk cair biourine rata-rata berat kering oven berangkasan tertinggi diperoleh pada dosis pupuk cair biourine $400 \mathrm{~L}^{-h^{-1}}$ (B2) yaitu 2,20 g dibandingkan dengan dosis pupuk cair biourine 200 L.ha $^{-1}$ (B1) yaitu 1,53 g dan perlakuan tanpa pupuk cair biourine (B0) yaitu 1,80 g serta dosis pupuk cair biourine 600 L.ha $^{-1}$ (B3) yaitu 2,20 g (Tabel 9). 
Tabel 9

Rata-rata Berat Kering Oven Berangkasan Karena Pengaruh Dosis Pupuk Kandang Ayam dan Pupuk Biourine

\begin{tabular}{|c|c|}
\hline Perlakuan & Berat Kering Oven Berangkasan $(\mathrm{g})$ \\
\hline \multicolumn{2}{|l|}{ Pupuk Kandang Ayam (K) } \\
\hline 0 ton ha-1 $(\mathrm{K} 0)$ & $1,75 \mathrm{a}$ \\
\hline 20 ton $\mathrm{ha}^{-1}(\mathrm{~K} 1)$ & $1,95 \mathrm{a}$ \\
\hline BNT 5\% & - \\
\hline \multicolumn{2}{|l|}{ Pupuk Cair Biourine (B) } \\
\hline $0 \mathrm{~L} \mathrm{ha}^{-1}(\mathrm{~B} 0)$ & $1,80 \mathrm{a}$ \\
\hline $200 \mathrm{~L} \mathrm{ha}^{-1}(\mathrm{~B} 1)$ & $1,53 \mathrm{a}$ \\
\hline $400 \mathrm{~L} \mathrm{ha}^{-1}(\mathrm{~B} 2)$ & $2,20 \mathrm{a}$ \\
\hline $600 \mathrm{~L} \mathrm{ha}^{-1}(\mathrm{~B} 3)$ & $1,87 \mathrm{a}$ \\
\hline BNT $0.05 \%$ & - \\
\hline
\end{tabular}

\section{Indeks Panen}

Rata-rata indeks panen tertinggi diperoleh pada perlakuan pupuk kandang ayam 20 ton.ha ${ }^{-1}$ (K1) yaitu 80,52 \% yang berbeda dengan perlakuan tanpa pupuk kandang ayam (K0) 79,41\%. Pada perlakuan pupuk cair biourine rata-rata indeks panen tertinggi diperoleh pada dosis pupuk cair biourine 400 L.ha $^{-1}$ (B2) yaitu 82,00\% dibandingkan dengan dosis pupuk cair biourine 600 L.ha $^{-1}$ (B3) yaitu 77,10\% dan perlakuan tanpa pupuk cair biourine (B0) yaitu $80,06 \%$ serta dosis pupuk cair biourine 200 L.ha $^{-1}$ (B1) yaitu $80,71 \%$ (Tabel 10$)$.

Tabel 10

Rata-rata Indeks Panen Karena Pengaruh Dosis Pupuk Kandang Ayam dan Pupuk Biourine

\begin{tabular}{|c|c|}
\hline Perlakuan & Indeks panen (\%) \\
\hline \multicolumn{2}{|c|}{ Pupuk Kandang Ayam (K) } \\
\hline 0 ton ha $^{-1}(\mathrm{~K} 0)$ & $79,41 \mathrm{a}$ \\
\hline 20 ton ha $\mathrm{a}^{-1}(\mathrm{~K} 1)$ & $80,52 \mathrm{a}$ \\
\hline BNT 5\% & - \\
\hline \multicolumn{2}{|c|}{ Pupuk Cair Biourine (B) } \\
\hline $0 \mathrm{~L} \mathrm{ha}^{-1}(\mathrm{~B} 0)$ & $80,06 \mathrm{a}$ \\
\hline $200 \mathrm{~L} \mathrm{ha}^{-1}$ (B1) & $80,71 \mathrm{a}$ \\
\hline $400 \mathrm{~L} \mathrm{ha}^{-1}(\mathrm{~B} 2)$ & $82,00 \mathrm{a}$ \\
\hline $600 \mathrm{~L} \mathrm{ha}^{-1}(\mathrm{~B} 3)$ & $77,10 \mathrm{a}$ \\
\hline BNT $0.05 \%$ & - \\
\hline
\end{tabular}

Perbandingan hasil penelitian dengan menggunakan benih didapatkan bahwa pertumbuhan tanaman kangkung yang dimulai dari benih memiliki tinggi tanaman tertinggi dibandingkan dengan yang dimulai dari punggul, akan tetapi jumlah cabang dan jumlah daunnya lebih rendah dibandingkan yang dimulai dari punggul dengan pemberian pupuk kandang dan biourin, sedangkan berat segar dan kering ekonomisnya lebih tinggi nilainya. Hal tersebut dikarenakan penanaman yang dimulai dari benih cenderung memiliki organ yang masih berfungsi dengan baik sedangkan yang dimulai dari punggul fungsi organ sudah mulai berkurang dalam menyalurkan zat hara dalam tanah ke seluruh bagian tanaman, Hal tersebut dikarenakan penanaman yang dimulai dari benih memiliki bagian tanaman seperti, akar dan batang dengan umur yang lebih muda dibandingkan yang dimulai dari punggul dimana kadar air, hasil metabolisme, dan keseimbangan respirasi dan fotosintesisnya cenderung lebih tinggi pada penanaman yang dimulai dari benih dibandingkan yang dimulai dari punggul (Tabel 11). 
Tabel 11

Pengaruh Dosis Pupuk Kandang Ayam dan Pupuk Biourine Terhadap Semua Variabel Yang Diamati Pada Hasil Panen Kesatu (Dimulai dari Benih) dan Panen Kedua (Dimulai dari Punggul)

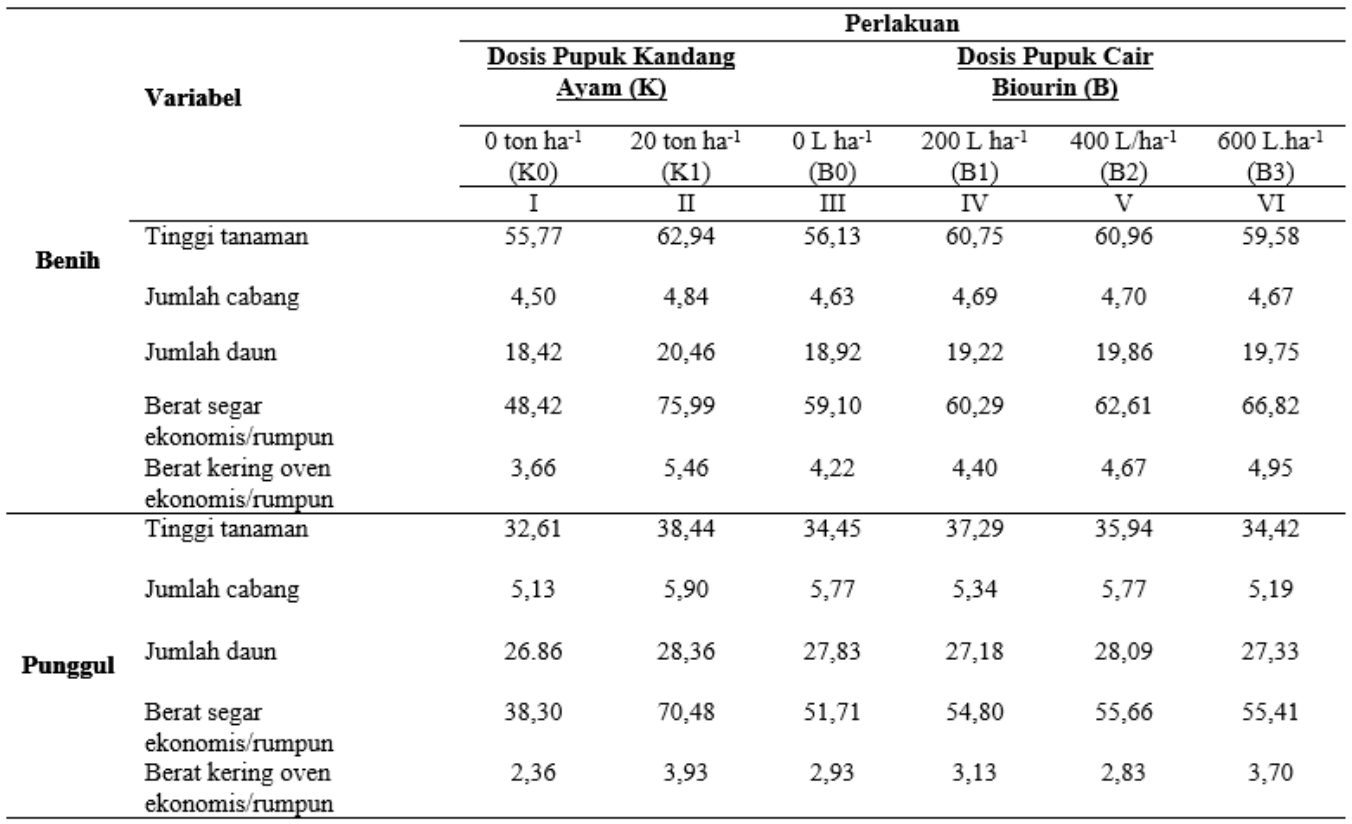

\section{Kesimpulan}

Perlakuan pupuk kandang ayam 20 ton $\mathrm{ha}^{-1}$ memberikan berat segar ekonomis per tanaman tertinggi yaitu 70,48 g dan meningkat sebesar 84,02\% dibandingkan dengan berat segar ekonomis per tanaman yang diperoleh pada perlakuan tanpa pupuk kandang ayam yaitu 38,30 g. Perlakuan dosis pupuk biourine $400 \mathrm{~L} \mathrm{ha}{ }^{-1}$ memberikan berat segar ekonomis per tanaman tertinggi yaitu 55,66 g dan meningkat sebesar 7,63\% dibandingkan dengan berat segar ekonomis per tanaman yang diperoleh pada perlakuan tanpa pupuk biourine yaitu 51,71 g. Tidak terjadi interaksi antara perlakuan pupuk kandang ayam dengan pupuk cair biourine terhadap semua variabel pertumbuhan dan hasil yang diamati pada tanaman kangkung darat kecuali variabel indeks panen. Hasil tanam ke-1 cenderung lebih baik dibandingkan dengan hasil tanam ke-2, tanaman hasil tanam ke-1 memiliki bagian tanaman seperti, akar dan batang dengan umur yang relatif lebih muda dan masih berfungsi dengan baik dibandingkan yang dimulai dari punggul.

Pupuk kandang ayam dengan dosis 20 ton $\mathrm{ha}^{-1}$ dan pupuk cair biourine dosis $400 \mathrm{~L} \mathrm{ha}^{-1}$ dapat digunakan untuk meningkatkan pertumbuhan dan hasil tanaman kangkung. Tanaman kangkung dapat ditanam berulang kali, akan tetapi hasil penanaman selanjutnya tidak sebaik dari hasil penanaman pertama dikarenakan pertumbuhan tanaman kangkung sudah mulai menurun.

\section{Referensi}

Aksi Agraris Kanisius ( 2002). Petunjuk Praktis Bertanam Sayuran. Penerbit Kanisius. Cetakan ke-VII. 175.

Nazaruddin (1995). Budidaya dan Pengaturan Panen Sayur Dataran Rendah. Penerbit PT. Penebar Swadaya. Jakarta. 142 hal.

Rismunandar, R. (1994). Bertanam Kangkung. Penerbit Kanisius Yogyakarta.

Rukmana, R. (1994). Bertanam Kangkung. Penerbit Kanisius. Yogyakarta. 44 hal. 
Suratman, Priyanto, D., \& Setyawan A.D. (2000). Analisis Keragaman Genus Ipomoea Berdasarkan Karakter Morfologi. Biodiversitas 1:72-79.

Sutari, N.W.S. (2010). Pengujian Kualitas Biourine Hasil Fermentasi dengan Mikroba yang berasal dari Bahan Tanaman terhadap Pertumbuhan dan Hasil Tanaman Sawi Hijau (Brassica juncea L.). Tesis. Program Studi Bioteknologi Pertanian, Program Pascasarjana, Fakultas Pertanian, Universitas Udayana, Denpasar.

Syekfani, (2000). Sifat dan Fungsi Pupuk Kandang. Malang. p. 89-93.

Widowati, L.R,. Widati, S., Jaenudin, U., \& Hartatik, W. 2005. Pengaruh Kompos Pupuk Organik Yang Diperkaya Dengan Bahan Mineral dan Pupuk Hayati terhadap Sifat-Sifat Tanah, Serapan Hara dan Produksi Sayuran Organik. Laporan Proyek Penelitian Program Pengembangan Agribisnis, Balai Penelitian Tanah 11(2): 123. 